Bangladesh J. Bot. 40(1): 57-65, 2011 (June)

\title{
DETECTION OF VIRUS PARTICLES AND DOUBLE-STRANDED RNA IN DIEBACK AFFECTED DALBERGIA SISSOO ROXB. FROM BANGLADESH
}

\author{
Stephanie Vogel, Hanny Tantau, Nicole Mielke-Ehret, MI Hoque ${ }^{1}$, \\ RH Sarker ${ }^{1}$, ML Saha ${ }^{1}$, Sk Shamimul Alam ${ }^{1}$, M Salim Khan ${ }^{2}$ \\ and Hans-Peter Mühlbach ${ }^{*}$
}

\author{
Molecular Phytopathology and Genetics, University of Hamburg, Biocentre Klein Flottbek, \\ Ohnhorststrasse 18, D-22609 Hamburg, Germany
}

Key words: Dieback disease, Sissoo, Double stranded RNA, Reverse transcription, DOP-PCR

\begin{abstract}
Dieback of Dalbergia sissoo Roxb. (sissoo) is a disastrous disease, which has destroyed millions of forest trees in South Asia. Plant pathogenic fungi and bacteria were found associated with diseased trees, but the causative disease agent has not yet been identified unequivocally. In order to see whether plant viruses could be detected in diseased trees, present author applied bioassays, transmission electron microscopy and double-stranded RNA (dsRNA) isolation, followed by cDNA cloning. Unknown virus particles and a complex pattern of dsRNA could be detected in leaf homogenates from dieback affected sissoo trees, in contrast to an uninfected tree. Disease associated dsRNA bands ranged in size from 0.6 to $3.5 \mathrm{kbp}$, and a cDNA clone derived from dsRNA showed partial sequence homology to a plant viral RNA polymerase. Our data indicated for the first time the presence of unknown virus(es) in dieback-affected Dalbergia sissoo in Bangladesh.
\end{abstract}

\section{Introduction}

Dalbergia sissoo Roxb. (Family Fabaceae, Subfamily Papilionoideae) is a tropical forest tree species, locally called shisham or sissoo. Its natural geographic distribution spans over a broad region in the Indian subcontinent at the foot of the Himalaya including Pakistan, India, and Nepal, usually at a geographical height between 900 and $1500 \mathrm{~m}$ (Southon 1994). Sissoo is cultivated in tropical regions world-wide as a valuable timber, which belongs to the group of palisander wood. In north and southwest of Bangladesh almost $60 \%$ of all forest plantations are sissoo plantations, thus demonstrating the economic importance of this timber species (Baksha and Basak 2003).

Since 1993 a severe disease called dieback has been recognized in several countries of the Indian subcontinent (Shukla 2002). The disease is characterized by a combination of symptoms, beginning with wilting of leaves. Later leaves become necrotic and fall down, as well as development of smaller twigs, leading to increasing crown transparency. Loss of branches follows and the disease ends up in the final stage of stagheadedness, where the affected trees loose almost all parts of the canopy. Black spots with gummosis appear on the base of the trunk and are found up to a height of three to five meters with progressing disease (Baksha and Basak 2003).

Various factors have been discussed as causes of the dieback disease. Abiotic factors have been suggested to contribute to the dieback of sissoo such as drought, flooding or soil conditions (Sharma et al. 2000), while other authors negate the importance of such factors (Webb and Hossain 2005). Fungi have been predominantly claimed as causative agents of dieback, including Fusarium solani, which was reported from India as early as in 1954 as putative agent of a disease on sissoo similar to dieback (Bakshi 1954). More recently a collection of various fungal species were detected in dieback affected sissoo (Dargan et al. 2002). However, none of these putative agents could be detected at all dieback affected sites (Baksha and Basak 2003) and in no case a

${ }^{*}$ Corresponding author: <muehlbach@botanik.uni-hamburg.de>. ${ }^{1}$ Department of Botany, University of Dhaka, Dhaka-1000, Bangladesh. ${ }^{2}$ Tissue Culture Laboratories, BCSIR, Dhaka-1205, Bangladesh. 
definite proof of the pathogens via fulfilling of Koch's postulates was shown. It is therefore, very likely that other or additional biotic agents such as bacteria, phytoplasms, viruses or viroids might also or primarily be involved in the dieback disease. Phytopathogenic bacteria as putative agents had been neglected until we could demonstrate by $16 \mathrm{~S}$ rDNA sequence analyses that bacteria of the genus Pseudomonas were associated with dieback affected sissoo trees from various sites in Bangladesh (Tantau et al. 2005). Diseases of trees caused by Pseudomonas species including $P$. syringae and its numerous pathovars are of major concern world-wide (Kennelly et al. 2007).

Similarly, neither viruses nor viroids have been studied so far in relation to dieback of sissoo, although these agents are well-known to cause serious diseases in forest trees (Nienhaus and Castello 1989). Recently, by using a strategy based on the isolation of double stranded RNA (dsRNA) and cDNA cloning, which allowed the molecular characterization of the complete viral genome, we could identify a novel virus now named European mountain ash ringspot-associated virus (EMARaV) (Mielke and Muehlbach 2007). Therefore, we decided to apply this strategy together with bioassays and transmission electron microscopy (TEM) in order to see whether virus particles or viral RNA could be detected in leaves of dieback affected Dalbergia sissoo trees.

\section{Materials and Methods}

Leaves of dieback affected Dalbergia sissoo trees were collected from various sites in Bangladesh, as shown in Table 1. Mixed leaf samples from various parts of each individual tree were used in this investigation. Samples P6 and P9 were collected at Sirajganj in the Eastern Rajshahi division, while the others were sampled at sites in the Dhaka division, P8 at Tangail, P20 and P22 at Mirzapur, and P29 - P33 at Pubail/Tangail. Severity of sissoo dieback disease was assessed in the following rating as shown in Table 1: 'No' disease means no typical symptoms of dieback, 'mild' disease with chlorosis and necrosis on leaves as well as initial crown transparency, 'medium' disease with strong leaf necrosis, advanced crown transparency, gummosis and necrosis (black spots) at the bottom parts of the trunk, while 'severe' disease means almost all foliage and most of twigs and branches of higher order lost (stagheadedness), and black spots at the trunk up to at least $2 \mathrm{~m}$ height. Collected leaves were kept cool and wet in sealed plastic bags for at maximum 48 hours during transport and finally stored at $-70^{\circ} \mathrm{C}$.

For bioassays the following herbaceous indicator plants were used: Nicotiana tabacum var. 'Xanthi' and 'Samsun', Chenopodium quinoa and Phaseolus vulgaris. Seeds were provided by Dr. C. Heinze (Department of Biology, University of Hamburg) or were obtained from the seed collection of the Botanical Garden, University of Hamburg. Plants were grown in the greenhouse under natural light at temperatures ranging from 16 to $30^{\circ} \mathrm{C}$. Bioassays were performed with homogenates made from dieback affected sissoo leaves in the following homogenisation buffers: $0.1 \mathrm{M} \mathrm{KH}_{2} \mathrm{PO}_{4}, \mathrm{pH} 7.0$, according to Fulton (1966); $0.1 \mathrm{M}$ sodium phosphate buffer ( $\mathrm{pH} 7.0$ ); 0.01 $\mathrm{M}$ potassium phosphate buffer ( $\mathrm{pH} 7.0$ ), containing $0.01 \mathrm{M} \mathrm{Na}_{2} \mathrm{SO}_{3}$, according to Chen et al. (2005). Sissoo leaves $(1 \mathrm{~g})$ were first ground in liquid nitrogen to a fine powder. Subsequently 2 or $20 \mathrm{ml}$ of the corresponding buffer were added, homogenized further, and used for inoculation of leaves of indicator plants dusted with carborundum (P320). Aliquots of $30 \mu 1$ of the original homogenate or in a dilution of 1/10 with the corresponding homogenization buffer were used per leaf. Alternatively, leaves of indicator plants were inoculated using the dry homogenized powder of sissoo leaves after grinding in liquid nitrogen without any buffer added, called dry inoculation according to Dr. Anan Kadri (unpublished, University of Stuttgart, Institute of Biology, Pfaffenwaldring 57, 70569 Stuttgart, Germany). For dry inoculation corresponding quantities of dry homogenates were used. The inocula were softly distributed on the leaves using sterile, frosted 
microscopic slides. Plants were kept for five weeks in the greenhouse under the same conditions as described above and visually inspected every third day.

For TEM studies aliquots of $0.5 \mathrm{~g}$ of sissoo leaves were homogenized in $100 \mathrm{ml}$ of $0.1 \mathrm{M}$ sodium phosphate buffer, $\mathrm{pH} 7.0$, or in $0.1 \mathrm{M}$ potassium phosphate, $\mathrm{pH}$ 7.0. Hexagonal nickel grids (300 mesh) coated with $0.5 \%$ pioloform (Plano GmBH Wetzlar, Germany) were placed onto $15 \mu \mathrm{l}$ drops of homogenate and incubated $5 \mathrm{~min}$ at $20^{\circ} \mathrm{C}$. The grids were washed with $40 \mu \mathrm{l}$ water and treated with $2 \%$ uranyl acetate solution for $2 \mathrm{~min}$. The grids were inspected using TEM Leo 906 E (Zeiss, Oberkochen, Germany).

The protocol of Benthack et al. (2005) was used for the isolation of dsRNA with some necessary modifications, as described under Results. Distilled water and all buffer solutions were treated with $0.1 \%$ DEPC before being autoclaved. Briefly, $20 \mathrm{~g}$ of leaves from dieback affected and non affected sissoo trees were homogenized in $80 \mathrm{ml}$ of homogenisation buffer and dsRNA was isolated through subsequent binding to CF11 cellulose. Contaminating DNA and single stranded RNA (ssRNA) were removed by incubation with DNase I and RNase A, respectively, in the presence of $0.3 \mathrm{M} \mathrm{MgCl}_{2}$. Preparations of dsRNA were analyzed in $1.0 \%$ agarose gels and documented after ethidium bromide staining in a GelVue UV transilluminator (Syngene). Size markers were Lamda DNA/EcoRI+HindIII, Gene Ruler DNA Ladder Low Range and Gene Ruler 100 bp DNA Ladder Plus (all from Fermentas, St. Leon-Rot, Germany).

Reverse transcription of dsRNA and degenerate oligonucleotide primed PCR (DOP-PCR) followed the protocol of Benthack et al. (2005). For optimising the protocol, PEG 1500 was added to a final concentration of $7 \%(\mathrm{w} / \mathrm{v})$ prior to the heating step. Reverse transcription was done using 20 units MMuLV reverse transcriptase (Fermentas) with the following temperature program: Ten min at $25^{\circ} \mathrm{C}, 25 \mathrm{~min}$ at $37^{\circ} \mathrm{C}, 25 \mathrm{~min}$ at $42^{\circ} \mathrm{C}$ (Mastercycler Gradient, Eppendorf, Hamburg). For DOP-PCR, aliquots of $5 \mu \mathrm{l}$ were taken from the reverse transcription mix, diluted by adding $35 \mu \mathrm{l}$ of sterile distilled water, denatured by heating $\left(5 \mathrm{~min}\right.$ at $\left.99^{\circ} \mathrm{C}\right)$ and were then immediately chilled on ice. Alternatively, $5 \mu \mathrm{l}$ aliquots were denatured by incubation together with 100 pmoles primer DOP1 (CCG ACT GCA GNN NNN NAT GTG, 20 pmol/ $\mu 1$, Metabion, Martinsried, Germany), and $144 \mu \mathrm{LMSO}$ at $65^{\circ} \mathrm{C}$ for $30 \mathrm{~min}$, after which nucleic acids were immediately precipitated, according to Jelkmann et al. (1989). Standard DOP-PCR mixture in a total volume of $50 \mu 1$ contained $5 \mu \mathrm{l}$ of the denatured cDNA (see above), 100 pmoles primer DOP1, $1 \mu 1$ of desoxynucleotide mixture (10 mM each, Fermentas), $5 \mu \mathrm{l}$ of $10 \mathrm{x}$ reaction buffer (Roche, Germany) and 1.5 units Taq DNA polymerase (Roche) according to the instruction in the DOPPCR Master Kit (Roche). The DOP-PCR program was exactly as described by Benthack et al. (2005). Aliquots of $10 \mu \mathrm{l}$ were analyzed in $1 \%$ agarose gels.

Cloning of PCR products was performed by using the pGEM-T Easy vector system (Promega) following the manufacturer's instructions. Recombinant plasmids were transformed into Escherichia coli DH5 $\alpha$ cells and recombinant clones were selected by blue-white screening, followed by standard PCR with vector-specific SP6/T7 primer pairs. Sequencing was carried out by using an Applied Biosystems ABI model 370A/373A automatic sequencer with BigDye Terminator kit (Applied Biosystems, Darmstadt, Germany). For sequence editing and primer selection, we used the DNAStar software LASERGENE. Database searching was done by using BLAST (NCBI).

To detect Fusarium spp. in the sissoo samples under study, PCR was performed using $500 \mathrm{ng}$ total nucleic acid preparations from sissoo leaves with a primer pair derived from the cutinase gene specific for Fusarium solani (Stahl and Schäfer 1992) as well as with the taxon-selective primer pair ITS-fu for the genus Fusarium (Abd Elsalam et al. 2003). 


\section{Results and Discussion}

Leaf homogenates from the dieback affected trees P6, P30, and P32 as well as from the unaffected and healthy looking tree P8 were prepared and subjected to transmission electron microscopy (TEM) after negative contrasting using uranyl acetate. In samples from the dieback affected trees we could observe particles ranging in size from $60 \mathrm{~nm}$ (Fig. 1A and C) up to $130 \mathrm{~nm}$ (Fig. 1B and D). The particles were more or less round shaped, resembling enveloped virus particles. In samples from the control tree P8 such typical structures were not observed. The particles detected in leaf homogenates of dieback affected sissoo resembled structures of enveloped virus particles found in diseased plants of unknown aetiology such as mountain ash ringfleck mosaic (Ebrahim-Nesbat and Izadpanah 1992) or fig mosaic disease (Martelli et al. 1993). In both cases, after intensive search multipartite viruses with negative-sense RNA genomes were found to be associated with the disease (Mielke and Muehlbach 2007, Elbeaino et al. 2009).
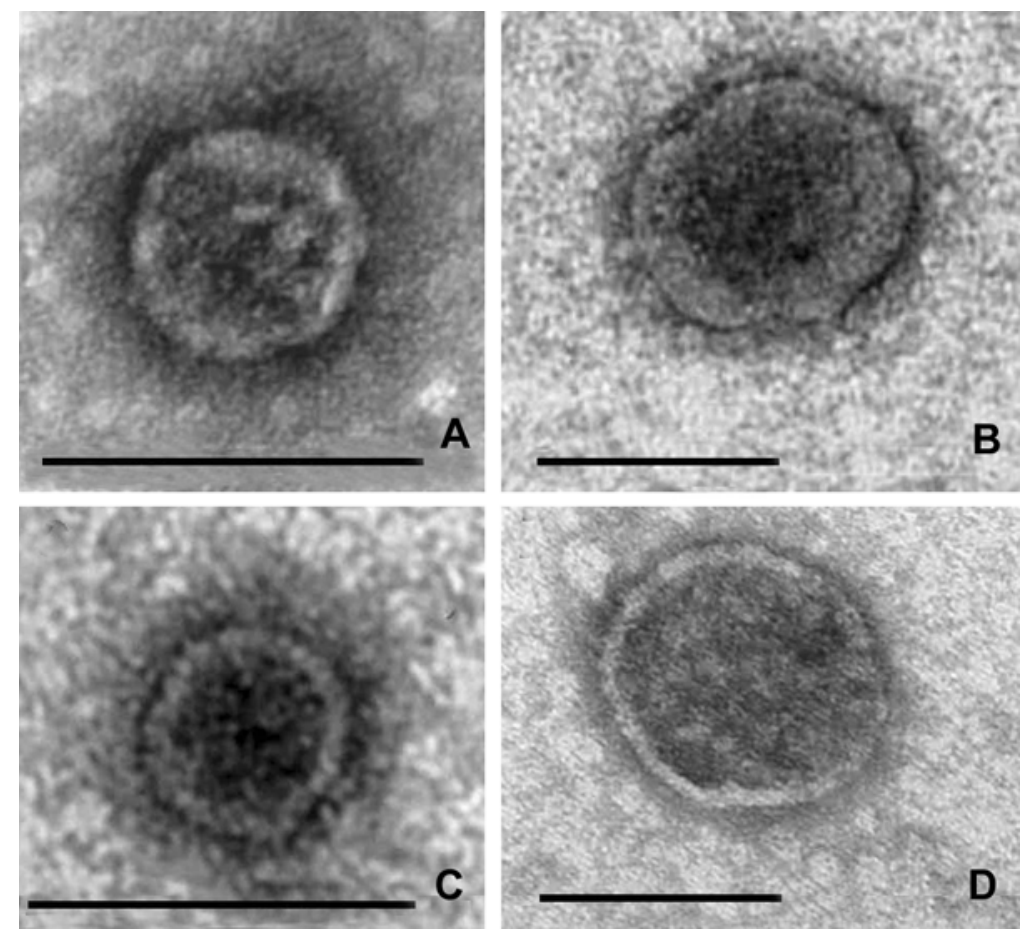

Fig. 1. Electron microscopic appearance of virus particles found in leaf homogenates from dieback affected Dalbergia sissoo trees after negative staining with uranyl acetate. A, C and D: P32; B: P30; Bars $=100 \mathrm{~nm}$.

When leaves from dieback affected trees of Dalbergia sissoo were subjected to dsRNA isolation by using the previously established protocol of Benthack et al. (2005), it became immediately evident that the original protocol had to be optimized for sissoo leaves. The volume of the extraction buffer had to be doubled in relation to the mass of leaf material used. In routine extraction, $20 \mathrm{~g}$ of frozen leaves were now homogenized with $80 \mathrm{ml}$ of extraction buffer. In addition, incubation time for RNase A digestion was raised up to $60 \mathrm{~min}$, instead of originally described $40 \mathrm{~min}$, and due to its high viscosity the aqueous sample had to be diluted by adding the 
same volume of sterile distilled water prior to phenol/chloroform extraction. The resulting dsRNA preparations proved to be RNase A and DNase I resistant. The profiles of dsRNA from nine individual samples as indicated in Table 1 were analyzed electrophoretically. Although the isolation procedure was adapted to the requirements of sissoo leaf material, the yield of dsRNA was still low, but the bands were clearly visible in ethidium bromide stained agarose gels. A few

Table 1. Patterns of dsRNA from dieback affected and from unaffected Dalbergia sissoo trees.

\begin{tabular}{|c|c|c|c|c|c|c|c|}
\hline \multirow{2}{*}{ Samples } & \multirow{2}{*}{ Site of collection } & \multirow{2}{*}{ Dieback symptoms } & \multicolumn{5}{|c|}{ Estimated size of dsRNA bands (kbp) } \\
\hline & & & 0.6 & 0.9 & 1.3 & 1.9 & 3.5 \\
\hline P 8 & Tangail & No & - & - & - & - & - \\
\hline P 6 & Sirajganj & Mild & + & - & - & - & + \\
\hline P 9 & Sirajganj & Mild & + & - & - & + & + \\
\hline P 22 & Mirzapur & Mild & + & + & + & - & + \\
\hline P 33 & Pubail/Tangail & Mild & + & + & - & + & + \\
\hline P 20 & Mirzapur & Medium & + & + & - & - & + \\
\hline P 29 & Pubail/Tangail & Medium & + & + & + & - & - \\
\hline P 32 & Pubail/Tangail & Medium & + & + & + & - & + \\
\hline P 30 & Pubail/Tangail & Severe & + & + & - & - & + \\
\hline
\end{tabular}

-, indicates no detectable dsRNA band of estimated size; + , indicates the presence of dsRNA band of estimated size.

examples of dsRNA profiles are shown in Fig. 2. Complex patterns of dsRNA bands were observed with dieback affected samples, ranging from $0.6 \mathrm{kbp}$ up to $3.5 \mathrm{kbp}$, which are summarized in Table 1. Sample P8 (healthy tree) was the only one from which no dsRNA fragments could be isolated (Fig. 2). A dsRNA band with $0.6 \mathrm{kbp}$ was found in all dieback affected samples, while the most slowly migrating dsRNA band at $3.5 \mathrm{kbp}$ was present in seven

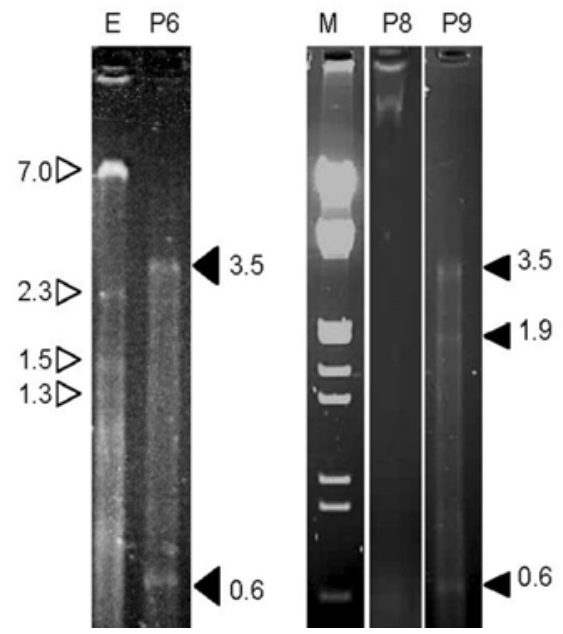

Fig. 2. Patterns of dsRNA from leaves of dieback affected and unaffected Dalbergia sissoo trees after electrophoresis in $1 \%$ agarose gels. P6, P9: dsRNA from dieback affected D. sissoo trees; P8: corresponding fraction from an unaffected tree. E: dsRNA from EMARaV-infected Sorbus aucuparia leaves used as control, the size of EMARaV dsRNA bands is indicated by open arrowheads $(\triangleright)$. $\downarrow$, position of dsRNA bands from $D$. sissoo leaves. M, DNA size marker Lambda /EcoRI+HindIII. Disease status of sample trees as indicated in Table 1. 
out of eight dieback affected samples (Table 1). This high molecular mass dsRNA was found in extracts made from samples with mild, medium and severe symptoms. Additional dsRNA bands at $0.9 \mathrm{kbp}$ were found in six dieback affected trees, while in three samples dsRNA at $1.3 \mathrm{kbp}$ was also detected and in two others at $1.9 \mathrm{kbp}$. The dsRNA patterns strongly indicated the association of a still unknown virus or viruses with dieback affected sissoo trees. To some extent the dsRNA patterns resembled the genome organisation of viruses with multipartite dsRNA genomes like mycoviruses (Nuss and Koltin 1990), which are often associated with plant pathogenic fungi (Pearson et al. 2009). The virus either reduces or increases the virulence of its fungal host, leading to mitigated or enhanced symptoms, respectively, of the fungal infection (Pearson et al. 2009). Since Fusarium solani had been reported to be associated with dieback (Bakshi 1954), we tested first the presence of $F$. solani by PCR, using total nucleic acid preparations from leaves of dieback affected trees P6, P30 and P33, and Cut1 primers specific for the cutinase gene of F. solani (Stahl and Schäfer 1992). With these primers F. solani was not detectable in the tested trees (Fig. 3A). Then we used the taxon-selective primer pair ITS-fu (Abd Elsalam et al. 2003), which indicated the presence of Fusarium spp. in trees P30 and P33 (Fig. 3B). Sequencing of the cloned PCR products showed best homology to Fusarium oxysporum. However, Fusarium associated mycoviruses such as FusoV (Nogawa et al. 1996) and FupoV (Compel et al. 1999) were not detected by PCR using conserved primer pairs (data not shown). Anyway, it is still likely that the evidence for viral infection is due to fungus associated mycoviruses.
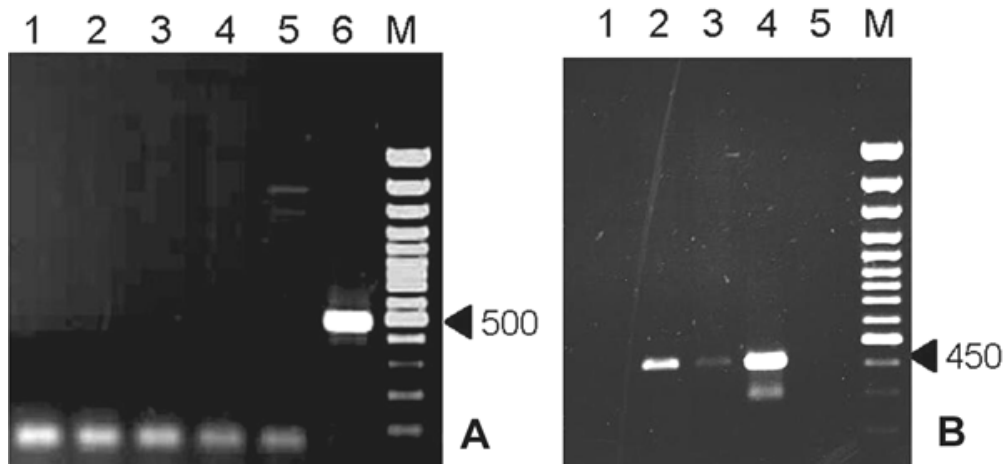

Fig. 3. Detection of Fusarium species in dieback affected Dalbergia sissoo leaves by PCR. (A) Cut1 primer pair specific for Fusarium solani. Lane 1: P8; 2: P6; 3: P30; 4: P33; 5: F. graminearum; 6: F. solani; M: Size marker Gene Ruler ${ }^{\mathrm{TM}} 100$ bp Ladder Plus. (B) ITS-fu primer pair specific for genus Fusarium. Lane 1: P6; 2: P30; 3: P33; 4: F. graminearum; 5: negative control, no template added; M: Size marker Gene Ruler $^{\mathrm{TM}} 100$ bp Ladder Plus.

However, the dsRNA pattern itself was not sufficient to conclude on the nature of the putative virus associated with sissoo trees. More information was expected from cloning and sequencing of the dsRNA fraction. We used our previously established protocol for reverse transcription and PCR of dsRNA from virus infected Sorbus aucuparia (Benthack et al. 2005). The most critical factors for efficient reverse transcription and PCR of dsRNA from Dalbergia sissoo were the complete denaturation of the dsRNA complexes on one hand and the presence of inhibitory compounds for PCR on the other hand. Amplification products from dsRNA of D. sissoo were only obtained, when denaturation and RT-PCR were done in the presence of 7\% PEG 1500 according to Pandey et al. (1996). PCR amplicons ranged in size from about 0.1 up to at least 1 kbp, which has been exemplarily shown for P33 and P6 (Fig. 4, Lanes 1 and 2). 
For sequence analyses, the complete RT-PCR products of the dsRNA preparation of tree P6 were cloned. Insert sizes ranged from about 150 to $700 \mathrm{bp}$. Only clones with inserts of more than $200 \mathrm{bp}$ in length were sequenced. While the majority of the sequences did not show homologies to already annotated plant or virus genes in databases, one clone (number 34) showed, on the basis of

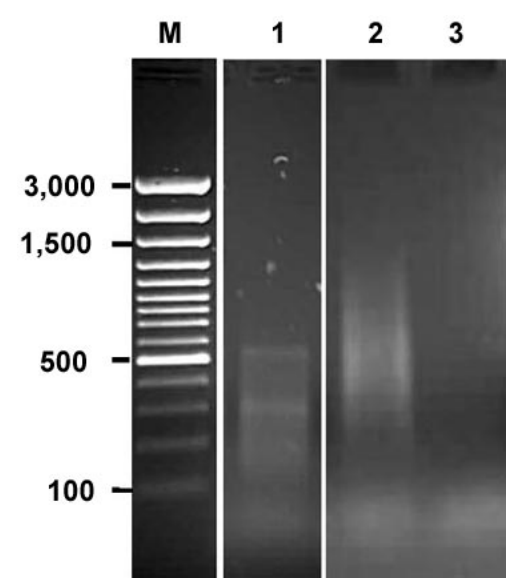

Fig. 4. DOP-PCR products with dsRNA preparations from leaves of dieback affected Dalbergia sissoo. Lane 1: P33; 2: P6; 3: negative control, no template added; M: Size marker Gene Ruler ${ }^{\mathrm{TM}} 100$ bp Ladder Plus.

deduced amino acids, $37.5 \%$ identity to the RNA dependent RNA polymerase (RdRp) of melon yellow spot virus (MYSV), a member of the genus tospovirus which belongs to the family Bunyaviridae (Okuda et al. 2004). The homologous sequence is located at the C-terminal region of the RdRp open reading frame of MYSV, as shown in Fig. 5. The sequence similarity is too low to allow any conclusion on the nature of the putative virus in sissoo trees. On the other hand, the electron microscopic investigation, dsRNA patterns and the sequence similarity of a cloned PCR fragment all together argue in favour of the presence of viral particles in the leaves of dieback affected sissoo.

\begin{tabular}{|cclllll|}
\hline Query & 226 & LNEPDGNSNFSIIISRHPCRHSDCDNPTKKNMKYN & 122 & Clone 34 \\
& & LNE D N + I + $\quad$ C SD D T+K + N & & \\
Subject 2786 & LNEKDANRKYEILENIRNCMTSDVDFLTEKCLYSN & 2820 & MYSV RdRp \\
\hline
\end{tabular}

Fig. 5. Comparison of the deduced amino acid sequence of cDNA clone no. 34 with part of the RdRp gene of melon yellow spot bunyavirus (MYSV). + , homologous amino acids.

However, all attempts to transmit the putative virus mechanically onto highly susceptible herbaceous indicator plants failed so far. After mechanical inoculation of typical indicator plants (Nicotiana tabacum, Chenopodium quinoa, Phaseolus vulgaris) with sissoo leaf homogenates prepared by four different homogenisation procedures, plants were observed over five weeks. In no case we could detect any visible symptoms on the plants, which had been inoculated with homogenates from leaves of dieback affected sissoo trees (not shown). On the other hand, this is not too surprising and might have several reasons, since not all viruses are easily transmissible by mechanical inoculation. Many of them require the specific and complex interaction with vectors like Frankliniella occidentalis, the vector of tospoviruses (summarized in German et al. 1992). In particular viruses of woody plants are very difficult to inoculate on herbaceous indicator plants. These viruses often show a very uneven distribution in various tissues and also reach only low 
titres (Garrett et al. 1985). Therefore the use of mixed samples, as has been carefully followed in the present study, is highly recommended. Inhibitory compounds in leaf homogenates, such as polyphenols and polysaccharides may interfere with mechanical transmission as well (Loebenstein 1972). As long as information on the nature of the putative virus in Dalbergia sissoo is still limited, appropriate techniques for efficient transmission onto herbaceous plants are difficult to establish.

It is still unknown to what extent a putative virus infection could contribute to the dieback disease of $D$. sissoo. There are very limited reports on the association of plant viruses with the dieback syndrome of woody plants. Bertioli et al. (1993) described the presence of a virus related to nepoviruses or comoviruses in an ash tree (Fraxinus sp.) with dieback, and cucumber mosaic virus (CMV) was detected in dieback affected kava (Piper methysticum) in Fiji (Davis et al. 2005). On the other hand, the association of phytopathogenic bacteria with dieback affected sissoo trees (Tantau et al. 2005) provides further evidence for a complex interaction of various pathogens in dieback affected sissoo trees. Since virus infected woody plants are thought to be more susceptible to non viral pathogens (Büttner and Nienhaus 1989), it is conceivable that viral infection of Dalbergia sissoo might contribute to the severity of the dieback disease.

\section{Acknowledgments}

Authors thank Heidrun Meyer and Dagmar Svensson for their excellent technical assistance, Elke Woelken for help with TEM studies and Dr. Conni Heinze for a gift of plant seeds. Primers for detection of Fusarium were kindly provided by Cathrin Kröger. This work was generously supported by Ilse and Matthias Tantau, the German Academic Exchange Service (DAAD), and Alexander von Humboldt Foundation.

\section{References}

Abd Elsalam AK, IN Aly, MA Abtel-Satar, MS Khalil and JA Verreet 2003. PCR identification of Fusarium genus based on nuclear ribosomal-DNA sequence data. Afr. J. Biotechnol. 2: 82-85.

Baksha MW and AC Basak 2003. Mortality of sissoo (Dalbergia sissoo Roxb.) and its management in Bangladesh. In: Mortality of sissoo (Dalbergia sissoo) and top dying of sundri (Heritiera fomes) in Bangladesh, MW Baksha (Ed.), pp. 1-6. Bangladesh Forest Research Institute, Chittagong.

Bakshi BK 1954. Wilt of shisham (Dalbergia sissoo Roxb.) due to Fusarium solani sensu Snyder and Hansen. Nature 174: 278-279.

Benthack W, N Mielke, C Büttner and HP Mühlbach 2005. Double-stranded RNA pattern and partial sequence data indicate plant virus infection associated with the ringspot disease of European mountain ash (Sorbus aucuparia L.). Arch. Virol. 150: 37-52.

Bertioli DJ, A Hayle and JI Cooper 1993. A new virus isolated from an ash tree with die-back. J. Phytopathol. 139: 367-372.

Büttner C and F Nienhaus 1989. Virus contamination of soils in forest ecosystems in the FRG. Eur. J. For. Path. 19: 47-53.

Chen TC, HT Hsu, RK Jain, CW Huang, CH Lin, FL Liu and SD Yeh 2005. Purification and serological analyses of tospoviral nucleocapsid proteins expressed by Zucchini yellow mosaic virus vector in squash. J. Virol. Methods 129: 113-124.

Compel P, I. Papp, M Bibo, C Fekete and L Hornok 1999. Genetic interrelationships and genome organization of double-stranded RNA elements of Fusarium poae. Virus Genes 18: 49-56.

Dargan JS, GS Dhingra, L Kuldeep and K Lalji 2002. Pathological problems and mycoflora associated with Dalbergia sissoo plantations in Punjab. Plant Disease Res.17: 269-277.

Davis RI, MF Lomavatu-Fong, LA McMichael, TK Ruabete, S Kumar and U Turaganivalu 2005. Cucumber mosaic virus infection of kava (Piper methysticum) and implications for cultural control of kava dieback disease. Australasian Plant Pathol. 34: 377-384. 
Ebrahim-Nesbat F and K Izadpanah 1992. Virus-like particles associated with ringfleck mosaic of mountain ash and a mosaic disease of raspberry in the Bavarian forest. Eur. J. For. Path. 22: 1-10.

Elbeaino T, M Digiaro, A Alabdullah, A De Stradis, A Minafra, N Mielke, MA Castellano and GP Martelli 2009. A multipartite single-stranded negative-sense RNA virus is the putative agent of fig mosaic disease. J. Gen. Virol. 90: 1281-1288.

Fulton RW 1966. Mechanical transmission of viruses of woody plants. Annu. Rev. Phytopathol. 4: 79-102.

Garrett RG, JA Cooper and PR Smith 1985. Virus epidemiology and control. In: The plant viruses. Vol. 1: Polyhedral virions with tripartite genomes, RIB Francki (Ed.), pp. 269-297. Plenum Press, New York.

German TL, DE Ullman and JW Moyer 1992. Tospoviruses: Diagnosis, molecular biology, phylogeny and vector relationships. Annu. Rev. Phytopathol. 30: 315-348.

Jelkmann W, RR Martin and E Maiss 1989. Cloning of four plant viruses from small quantities of doublestranded RNA. Phytopathol. 79: 1250-1253.

Kennelly MM, FM Cazorla, A De Vicente, C Ramos and GW Sundin 2007. Pseudomonas syringae diseases of fruit trees - Progress toward understanding and control. Plant Dis. 91: 4-16.

Loebenstein G 1972. Transmission of viruses by mechanical inoculation. In: Principles and techniques in plant virology, CI Kado and HO Agrawal (Eds), pp. 32-61. Van Nostrand Reinhold, New York.

Martelli GP, MA Castellano and R Lafortezza 1993. An ultrastuctural study of fig mosaic. Phytopathol. Mediterra. 32: 33-43.

Mielke N and HP Muehlbach 2007. A novel, multipartite, negative-strand RNA virus is associated with ringspot disease of European mountain ash (Sorbus aucuparia L.). J. Gen. Virol. 88: 1337-1346.

Nienhaus FJ and D Castello 1989. Viruses in forest trees. Annu. Rev. Phytopathol. 27: 165-186.

Nogawa M, T Kageyama, A Nakatami, G Taguchi, M Shimosaka and M Okazaki 1996. Cloning and characterization of mycovirus double-stranded RNA from the plant pathogenic fungus Fusarium solani f. sp. robiniae. Biosci. Biotechnol. Biochem. 60: 784-788.

Nuss DL and Y Koltin 1990. Significance of dsRNA genetic elements in plant pathogenic fungi. Annu. Rev. Phytopathol. 28: 37-58.

Okuda M, K Kato, K Hanada and T Iwanami 2004. Complete nucleotide sequence of L RNA segment of melon yellow spot virus. Jpn. J. Phytopathol. 70: 14-17.

Pandey RN, RP Adams and E Flournoy 1996. Inhibition of random amplified polymorphic DNAs (RAPDs) by plant polysaccharides. Plant Mol. Biol. Reporter 14: 17-22.

Pearson MN, RE Beever, B Boine and K Arthur 2009. Mycoviruses of filamentous fungi and their relevance to plant pathology. Mol. Plant Pathol. 10: 115-128.

Sharma MK, RM Singal and TC Pokhriyal 2000. Dalbergia sissoo in India. In: Proceedings of the SubRegional Seminar "Die-back of sissoo (Dalbergia sissoo)", S Appanah, G Allard and SM Amatya (Eds), pp. 5-16. Kathmandu, Nepal, April, 25-28, 2000, Forestry Research Support Programme for Asia and Pacific (FORSPA), Bangkok.

Shukla AN 2002. Mortality of Dalbergia sissoo in India. Indian Forester 128: 1209-1215.

Southon IW 1994. Phytochemical dictionary of the Leguminosae. Chapman \& Hall, London.

Stahl JD and W Schäfer 1992. Cutinase is not required for fungal pathogenicity on pea. Plant Cell 4: 621629.

Tantau H, MI Hoque, RH Sarker and HP Mühlbach 2005. 16S rDNA sequence analysis of bacterial isolates from die-back affected sissoo trees (Dalbergia sissoo Roxb.) in Bangladesh. J. Phytopathol. 153: 517521.

Webb EL and SMY Hossain 2005. Dalbergia sissoo mortality in Bangladesh plantations: correlations with environmental and management parameters. For. Ecol. Manage. 206: 61-69. 